\title{
Life cycle analysis of external costs of a parabolic trough Concentrated Solar Power plant
}

\author{
Norah Mahlangu, George Alex Thopil \\ Department of Engineering and Technology Management, University of Pretoria
}

\begin{abstract}
A number of developing countries have undertaken measures to diversify into renewable electricity generation. Concentrated Solar Power (CSP) is one of the technologies, though despite the high capital costs have numerous technological capabilities. CSP however is a new technology in many developing countries, where the external costs have not been fully understood. Thus far, South Africa has not conducted any detailed externalities assessments for renewable electricity sources. The presented research aims to evaluate the external cost associated with a solar CSP plant using life cycle analysis. The analysis uses a parabolic trough CSP plant with 100MW capacity located in the Northern Cape region in South Africa.
\end{abstract}

The analysis evaluated external impacts and costs for climate change, human health, loss of biodiversity, local effects on crops, and damage to materials. The study found that climate change accounted for an estimated $32.2 \mathrm{~g} \mathrm{CO}_{2} \mathrm{eq} / \mathrm{kWh}$ of electricity generated. A number of non-greenhouse gas impacts were also analysed of which the effect on human health was the most significant category $(0.214 \mathrm{~g} / \mathrm{kWh})$. The damage cost quantified in the study for the solar CSP plant was in the range of 2.10-3.31 ZA c/kWh (1.4-2.2 €/MWh) with a central estimate of $2.83 \mathrm{ZA} \mathrm{c} / \mathrm{kWh}(1.9 € / \mathrm{MWh})$. The results suggested that climate change and human health had a combined contribution of $91 \%$ to the central estimate of the external costs which was mostly attributed by the manufacturing life cycle phase. The analysis showed that manufacturing activities have a major contribution across all impact categories. A major policy understanding is that the overall damage costs can be reduced if manufacturing the main components can be localised, to reduce the emissions caused by the transport systems. This could bring added benefits for local communities and industries.

Keywords: Life Cycle Analysis, Concentrated Solar Power, Greenhouse gas, Human health, Damage cost

$\begin{array}{ll}\text { List of notations and abbreviations } \\ c_{\text {study }} & \text { Thermal capacity of power plant within study } \\ c_{\text {ref }} & \text { Thermal capacity of reference power plant } \\ m_{\text {study(solar field or HTF) }} & \text { Mass of the solar field or HTF components of the power plant within } \\ & \text { study } \\ m_{\text {ref(solar field or HTF) }} & \text { Mass of the solar field or HTF components of reference power plant } \\ m_{\text {study(Power Plant) }} & \text { Mass of power plant components within study } \\ m_{\text {ref(Power Plant) }} & \text { Mass of power plant components of reference power plant } \\ m_{\text {study(TES) }} & \text { Mass of the thermal storage components of power plant within study } \\ m_{\text {ref(TES) }} & \text { Mass of the thermal storage components of reference power plant } \\ \text { CSP } & \text { Concentrated Solar Power } \\ \text { HTF } & \text { Heat Transfer Fluid } \\ \text { IRP } & \text { Integrated Resource Plan } \\ \text { LCA } & \text { Life Cycle Assessment } \\ \text { LCC } & \text { Life Cycle Costing } \\ \text { NMVOC } & \text { Non-Methane Volatile Organic Compounds } \\ \text { PPM } & \text { Primary Particulate Matter } \\ \text { REIPPP } & \text { Renewable Energy Independent Power Producer Procurement } \\ & \text { Programme } \\ \text { TES } & \text { Thermal Energy Storage }\end{array}$




\section{Introduction}

The electricity generation sector has seen a rapid growth in renewable energy injection due to the need to reduce carbon emission into the atmosphere. In the past coal was considered the cheapest energy source for electricity production; which delayed the adoption of renewable energy technologies (Huenteler et al., 2016). Electricity generation using coal provides baseload electricity compared to the intermittency of renewable energy such as solar and wind (Vezmar et al., 2014).

There are predominantly two ways in which electricity can be generated using solar energy (Tsoutsos et al., 2005), (Desai and Bandyopadhyay, 2015), either by using the photovoltaic system which uses direct sunlight; directly to the solar panels to generate electricity or by using the CSP which uses mirrors to concentrate the sun rays to heat steam or gas that turns a turbine to produce electricity. Solar CSP technology which is the main focus of this research consists of four technologies, namely parabolic trough (uses parabolic troughs mirrors to concentrate the sun rays to the fluid which in turn heats the steam to drive the turbine to generate electricity), linear fresnel reflector (consist of a long and thin segment of mirrors that focus the run rays to the fixed absorber where the heat is transferred to the heat exchanger to run the steam generator to produce electricity), solar towers (uses heliostats to focus the sun rays onto a central receiver to heat the fluid to produce steam to generate electricity) and the parabolic dish (uses a mirror shaped in the form of a dish to concentrate the sun rays onto a central receiver where the thermal energy is used to produce energy) (Khan and Arsalan, 2016). Parabolic trough technology however is the more developed and widespread compared to the other technologies (Khan and Arsalan, 2016). Parabolic trough technology has the ability to store energy using molten salt which is an added benefit compared to wind and solar PV thus providing lesser intermittency (Viebahn et al., 2008), (Kuravi et al., 2013).

A major advantage of solar CSP is its flexibility when it comes to configurations (San Miguel and Corona, 2014). Studies have been performed internationally for the hybridisation of solar CSP plants to produce electricity by limiting the fossil fuel reliance. The system can be paired with other cleaner energy sources to form a hybrid system such as natural gas, biomass, etc. The main objective of hybridisation is to integrate the solar CSP plant's Rankine cycle with another plant which can as a result reduce the cost of the CSP plant by $50 \%$ by eliminating the need for the storage system (Peterseim et al., 2014). It was also found in the study by Peterseim et al. (2014) that the ranking cycle components of the solar CSP paired well with natural gas and biomass, where biomass can be considered the cleaner energy of the two sources. Natural gas external costs were found to be 8.6 times higher than solar only operated plants in the Corona et al. (2016) study and also found to have 4-9 times more life cycle greenhouse gas emissions in the study by Klein and Rubin (2013). Hence there is a need to look into cleaner alternatives to pair with solar CSP plants. Although there are several plants around the world which takes into account hybridisation, the likelihood of South Africa adopting hybridisation is minimal because of the lack of natural gas supply infrastructure.

$91.5 \%$ of the electricity production in South Africa is from coal with the country's coal dependence making it a major emitter of greenhouse gases (IEA, 2017). South Africa has invested in two biggest coal fired power station (Medupi and Kusile power stations) to meet the current electricity demand and again more coal is planned to introduced prior to 2030 (DoE, 2013). Electricity generation in South Africa using coal or fossil fuels have been closely linked to emitting harmful pollutants and greenhouse gases (GHG) in the form of environmental costs (Thopil, 2013), including occupational costs (Thopil and Pouris, 2011) and public costs (Thopil and Pouris, 2015). Earlier studies looked at accounting positive benefits of electrification (Spalding-Fecher and Matibe, 2003) as well as impacts at household level (Van Horen, 1996a) and (Van Horen, 1996b). The effects of harmful - both 
GHG and non GHG - emissions, are called externalities when these effects are not incorporated to the total cost of the product life (Corona et al., 2016), or even at national level (Georgakellos, 2012) and hence these can cause health risks when inhaled as pollutants (Zvingilaite, 2011) or affect the economy (Chen et al., 2015). South African investigations encouraged future externality studies to be expanded to include renewable sources (Thopil and Pouris, 2015).

Currently there are no studies that have attempted to evaluate externalities for renewable electricity sources, in South Africa. This research therefore aims to determine externalities associated with parabolic trough CSP in South Africa by the means of life cycle analysis, to identify the main impacts and phases during the life cycle that contribute to the externalities and then quantify the monetary impact (external costs) associated with the externalities. Life cycle analysis has proven popular to identify the total costs (both internal and external) of a process such in municipal wastewater (Theregowda et al., 2016), transport sub-system (Sen et al., 2017) or building system (Chiang et al., 2015). Externality investigations on renewable sources in South Africa is fairly unchartered grounds (Rudman et al., 2016). The investigation aims to contribute by developing a methodology to estimate local CSP power plant inventory data from international data, when local data is not available or accessible. This can be particularly useful for developing countries where technologies (or parts) are imported and local developers maybe unwilling to share data.

\section{Background}

South Africa has introduced market incentives to promote renewable energy technologies, for example the introduction and the success of the Renewable Energy Independent Power Producer Procurement Programme (REIPPPP) which drives the future injection of renewable energy and bringing South Africa closer to its 2030 target with reference to the national electricity plan (DoE, 2013). South Africa's REIPPPP programme provides a framework to encourage private sector investment in renewable energy for the country. The programme has landed South Africa in the top list of the Fieldstone Africa Renewables Index (Fieldstone Africa, 2017) for delivering results on a large scale. South Africa has proposed the introduction of a carbon tax, which is aimed at encouraging companies to reduce their greenhouse emissions by coming up with new and innovative ways to generate electricity (DoE, 2013). This makes the move to diversify electricity production by adding renewable energy sources not only a national goal but also aligning with the global initiative.

Among the many renewable sources that South Africa plans to introduce into the system; solar CSP will also form part of the future energy mix (DoE, 2013). According to (Rudman et al., 2016) South Africa currently has six CSP plants allocated, and totalling 600MW which is roughly $12 \%$ of total renewable allocation. Within the $600 \mathrm{MW}, 450 \mathrm{MW}$ is allocated to parabolic trough CSPs, with the rest being central tower CSP based. Hence this research study focuses on CSP parabolic trough system. The objective of this research is to evaluate externalities, to identify the main impacts and phases during the life cycle that contribute to the externalities and to measure the monetary impact for the externalities. 


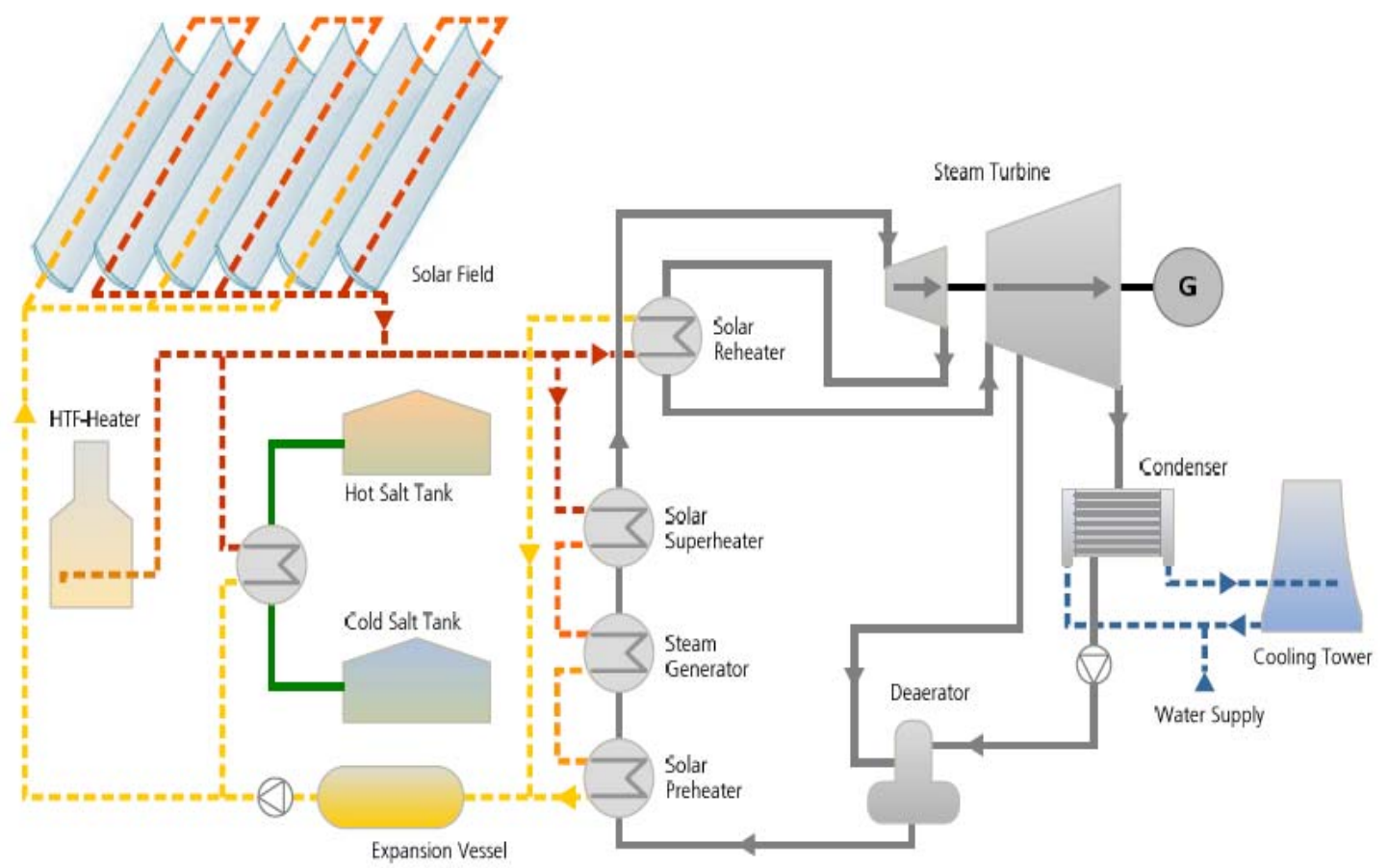

Figure 1: KaXu Solar One schematic

Source:(KaXu Solar One (Pty) Ltd, 2012)

The lifecycle assessment analysis in this study is based on the solar CSP plant called KaXu Solar One. KaXu Solar One is the first CSP power plant to be built in South Africa, and started commercial operation in February 2015. KaXu Solar is a parabolic trough CSP plant located in the Northern Cape region of South Africa. The power plant has an installed capacity of $100 \mathrm{MW}$, with a rated capacity factor of $36.5 \%$ (translating to roughly $320 \mathrm{GWh} /$ year of produced electricity). The CSP plant occupies 1100 ha of land, has a life expectancy of 20 years and benefits from a direct normal irradiation (DNI) of $2900 \mathrm{kWh} / \mathrm{m}^{2}$ (Rudman et al., 2016) with a solar field aperture area of $800000 \mathrm{~m}^{2}$ using 1200 solar collector assemblies which uses thermal oil as heat transfer fluid (HTF). The installation incorporates 2.5 hour thermal energy storage (TES) system based on two-tank indirect molten salt technology. The plant was developed by Abengoa which is based in Spain. Figure 1 shows a schematic diagram of the KaXu Solar CSP plant (KaXu Solar One (Pty) Ltd, 2012),(National Renewable energy laboratory, 2016). South Africa has minimal experience in solar CSP with most of the skills provided by the US and Spain (Rudman et al., 2016). This has led to the significant portions of the infrastructure required to build the CSP plant being imported from other countries.

It becomes essential to estimate the cost of externalities in electricity generation to provide the real cost of electricity production in order to make an informed argument about which electricity sources are cost competitive, and also to minimise the externalities. Studies have shown that when the monetary cost of the externalities produced during electricity generation using coal or conventional fossil sources is included in the normal costs, the cost of electricity can be considered high (Thopil and Pouris, 2011, Thopil and Pouris, 2015, Rentizelas and Georgakellos, 2014, Thopil and Pouris, 2010, Meyerhoff et al., 2010). Determining total external costs aid in creating an understanding of how overall processes can be made more efficient and also help in comparison of external cost with other technologies. This will enable both technical and policy decision making both on an engineering level as well as policy makers in decisions relating to energy and electricity related planning. 


\subsection{International Solar CSP Externality studies}

Corona et al. (2016) evaluated the full environmental life cycle cost analysis of concentrating solar power technology; which included manufacturing, construction, operation and maintenance, dismantling and disposal. The analysis was based on a case study for a $50 \mathrm{MW}$ plant situated in the southern Spain. The plant operated in hybrid mode, solar and natural gas, with the natural gas input ranging from $0 \%$ to $30 \%$. The analysis divided the external cost into six categories namely human health, loss of biodiversity, local and global damage to crops, damage to materials and climate change. The study used the life cycle analysis (LCA) methodology to determine the impacts of the CSP plants and the life cycle costing (LCC) approach to determine the damage cost of the impacts. The damage cost for the project was calculated using the CASES (CASES, 2008) project for the LCA. Cost assessment of sustainable energy systems (CASES) projects is an extension of the Extern $\mathrm{E}$ projects; the research evaluates the LCA of case studies with the aim of determining the cost of the externalities. The study found that the external unit costs of CSP with $30 \%$ natural gas were up to 8.6 times higher than in solar-only operation, primarily due to increased greenhouse gas emissions and solar-only operation remains the best option (Corona et al., 2016). The research study found that the highest contributor to the total impacts was from the climate change sub category with $27.6 \mathrm{~kg} \mathrm{CO}$ eq/MWh for environmental impacts and a total damage cost in the range of 0.906 and $1.18 € / \mathrm{MWh}$ (realistic and ambitious scenario respectively).

The research conducted by Turney and Fthenakis (2011) took into account the installation and operation phases of a CSP. Turney and Fthenakis (2011) argue that most published scientific research on environmental impacts from solar power use a LCA framework, and typically the interest of the investigations are on greenhouse gas emissions and the energy payback time. The study also notes that most research does not investigate hazardous materials emissions, land use intensity, water usage, wildlife impacts, and albedo effects (the reflection of the sun back to space). Thus the study evaluated the land use intensity, human health and wellbeing, plant and animal life, geo-hydrological resources, as well as climate change. It was noted that solar energy requires a reasonable amount of land and that the land cannot be used for anything else other than for electricity production, as opposed to wind energy where the land can also be used for farming purposes. It was also noted that there is carbon dioxide emission (up to $36 \mathrm{~g} \mathrm{CO}_{2}$ eq/kWh emissions) during the removal of forests to make way for the solar plant (and minimal emission at a desert region) compared to $1100 \mathrm{~g} \mathrm{CO}_{2} \mathrm{eq} / \mathrm{kWh}$ for coal base electricity. There were more benefits to a solar power plant located at the desert than one located at forest region due to minimal to no wildlife present in the desert with more exposure to the sun (total emissions 16 and $86 \mathrm{~g} \mathrm{CO}_{2}$ $\mathrm{eq} / \mathrm{kWh}$ due to clearing of vegetation).

In CSP plants the emissions that occur from using fossil fuel energy for the operational phase, are due to the natural gas use and electricity consumption (Lechon et al., 2008). The energy required to build and to decommission a CSP power plant was $0.17 \mathrm{MJ} / \mathrm{kWh}$ for the central tower technology and $0.19 \mathrm{MJ} / \mathrm{kWh}$ for the parabolic trough technology (Lechon et al., 2008), implying that more energy is required to decommission the parabolic trough systems.

In the Klein and Rubin (2013) study, the authors explored the greenhouse gas emissions, water and land use for CSP that uses molten salt for the thermal energy storage (TES). TES is used to reduce the dependency on fossil fuels as a backup and as a result this reduces the amount of greenhouse gas emissions. The study considered a $110 \mathrm{MW}$ gross capacity parabolic trough plant operating with two different cooling technologies, three different energy backup system options, and 12 different backup system capacities. The study also used the LCA methodology to conduct the study, where it compared the effects of the different backup storage; natural gas-fired, heat transfer fluid heater, and minimal backup and found that natural gas operations emit more greenhouse gases compared to TES, and 
also that the TES system had twice as more greenhouse gas emissions compared to the minimum backup system.

The study also aimed to estimate the difference between the different cooling systems; dry and wet cooled to determine the systems water consumption and emissions. It thus commended dry cooling technology for its reduction in water consumption by 71 to $78 \%$ compared to using the wet cooling system. They also found that the backup capacity that the CSP plant employs is directly proportional to the water consumption. The amount of land required for each megawatt (land/MWh) for a CSP plant was found to increase with increasing TES capacity and decreased with increasing natural gas backup system capacity. The authors recommended that future studies should examine policy options to motivate the use of dry cooling in new CSP parabolic trough plants due dry cooling having the ability to minimise onsite operational water use by up to $93 \%$ in desert areas without significantly increasing lifecycle GHG emissions or land use.

Burkhardt et al. (2012) aimed to reduce the variability of impacts and to have an estimate on the greenhouse gas emissions for tower and trough CSP generation lifecycle, by using a process called harmonization where 125 papers from different countries and different case studies over different periods where reviewed to gather the findings. They found that the range of lifecycle greenhouse gas emissions was $26 \mathrm{~g} \mathrm{CO}_{2} \mathrm{eq} / \mathrm{kWh}$ for a parabolic trough and $38 \mathrm{~g} \mathrm{CO}_{2} \mathrm{eq} / \mathrm{kWh}$ for tower.

In another investigation by (Burkhardt III et al., 2011) where analysis was based on a case study, it was noted that there were challenges with water shortages in the power sector, so they performed a study on different cooling systems of the solar CSP which aims to show the differences between the two system in the form of saving water (wet and dry cooled system). The study used the life cycle model to analyse a 103MW wet and dry cooled solar CSP and also determined the greenhouse gases for the systems. The study used the EIO-LCA model to estimate the emissions embodied by the plant components such as pumps, compressors, turbine generator set, and miscellaneous controls and electronic equipment. The study found the greenhouse gases for the wet cooled system to sum up to $26 \mathrm{~g} \mathrm{of} \mathrm{CO}_{2} \mathrm{eq} / \mathrm{kW}$, and consumed $4.7 \mathrm{l} / \mathrm{kWh}$ and has an energy demand of $0.40 \mathrm{MJ} \mathrm{eq} / \mathrm{kWh}$. The dry cooled system was estimated to reduce water consumption by $77 \%$ but increase greenhouse emissions by $8 \%$.

Overall, it can observed from literature that the use of the LCA model is quite prominent to evaluate the impacts for solar CSP including parabolic trough technology. The results stipulated in Table 1 show the climate change emissions from different studies. Although the results are from different authors in different locations, the difference in the results is minimal with a range from 14-33.4 $\mathrm{g} \mathrm{CO}_{2} \mathrm{eq} / \mathrm{kWh}$ in the climate change sub-category for the parabolic trough technology. 
Table 1: Comparison of climate change impacts of CSP technologies

\begin{tabular}{|c|c|c|c|c|c|}
\hline Study & $\begin{array}{l}\mathrm{g} \mathrm{CO}_{2} \\
\mathrm{eq} / \mathrm{kWh}\end{array}$ & Study Location & System layout & Summary of the study & Methodology \\
\hline $\begin{array}{l}\text { Corona et al. } \\
\text { (2016) }\end{array}$ & 27.6 & Spain & $\begin{array}{l}\text { Wet cooled 50MW parabolic } \\
\text { trough CSP life cycle } \\
\text { expectancy } 25 \text { years, two } \\
\text { tank molten salt and also } \\
\text { uses synthetic oil as the HTF }\end{array}$ & $\begin{array}{l}\text { The study estimates the life cycle } \\
\text { cost of a 50MW parabolic trough } \\
\text { CSP plant operating in hybrid } \\
\text { mode in Spain with different } \\
\text { natural gas inputs from zero to } \\
\text { thirty percent, with solar } \\
\text { irradiation of } 2200 \mathrm{kWh} / \mathrm{m}^{2} \mathrm{yr}\end{array}$ & $\begin{array}{l}\text { Life cycle } \\
\text { assessment }\end{array}$ \\
\hline $\begin{array}{l}\text { Burkhardt III } \\
\text { et al. (2011) }\end{array}$ & 28 & United states & $\begin{array}{l}\text { The dry cooled system is a } \\
103 \mathrm{MW} \text { parabolic trough CSP } \\
\text { with life expectancy of } 30 \\
\text { years. Two tank molten salt } \\
\text { storage and uses thermal oil } \\
\text { as the HTF }\end{array}$ & $\begin{array}{l}\text { The study evaluates the } \\
\text { greenhouse gas emissions of a } \\
\text { parabolic solar CSP plant in the } \\
\text { United States, using the life cycle } \\
\text { assessment methodology, with } \\
\text { solar irradiation of } 2700 \mathrm{kWh} / \mathrm{m}^{2} \mathrm{yr}\end{array}$ & $\begin{array}{l}\text { Life cycle } \\
\text { assessment }\end{array}$ \\
\hline $\begin{array}{l}\text { Viebahn et al. } \\
(2008)\end{array}$ & 33 & Spain and Algeria & $\begin{array}{l}46 \mathrm{MW} \text { parabolic trough CSP } \\
\text { plant with HTF thermal oil and } \\
\text { molten salt storage }\end{array}$ & $\begin{array}{l}\text { The study forms part of the } \\
\text { NEEDS project. It models a } \\
\text { different Solar CSP systems } \\
\text { (parabolic trough, central } \\
\text { receiver, etc) to estimate the } \\
\text { impacts and the external cost of } \\
\text { each for various impacts } \\
\text { (GHG,NOx,SOx etc.), with solar } \\
\text { irradiation between } 2000 \text { and } \\
2500 \mathrm{kWh} / \mathrm{m}^{2} \mathrm{yr}\end{array}$ & $\begin{array}{l}\text { LCA (Impact } \\
\text { Pathway) }\end{array}$ \\
\hline $\begin{array}{l}\text { Desideri et al. } \\
(2013)\end{array}$ & 29.9 & Italy & $\begin{array}{l}\text { 2MW solar CSP parabolic } \\
\text { trough plant with no storage } \\
\text { system. }\end{array}$ & $\begin{array}{l}\text { Performed a comparative } \\
\text { analysis using the lifecycle } \\
\text { assessment analysis for solar } \\
\text { CSP and Photovoltaic } \\
\text { technologies in Italy, with solar } \\
\text { irradiation between } 1600-1800 \\
\mathrm{kWh} / \mathrm{m}^{2} \mathrm{yr}\end{array}$ & $\begin{array}{l}\text { Life cycle } \\
\text { assessment }\end{array}$ \\
\hline $\begin{array}{l}\text { Burkhardt et } \\
\text { al. (2012) }\end{array}$ & 26 & United states & $\begin{array}{l}\text { A qualitative research study to } \\
\text { establish a single acceptable }\end{array}$ & $\begin{array}{l}\text { Review of life cycle literature for } \\
\text { Solar CSP from } 12 \text { reviewed }\end{array}$ & $\begin{array}{l}\text { Harmonization } \\
\text { Method }\end{array}$ \\
\hline
\end{tabular}




\begin{tabular}{|l|l|l|l|l|l|}
\hline & & & value & $\begin{array}{l}\text { references, 10 produced } \\
\text { references and 36 independent } \\
\text { GHG emissions estimates; where } \\
19 \text { was for parabolic trough and } \\
17 \text { for power tower technology. }\end{array}$ & \\
\hline $\begin{array}{l}\text { Arvizu et al. } \\
(2011)\end{array}$ & $14-32$ & Multiple countries & $\begin{array}{l}\text { A qualitative research study to } \\
\text { establish a single acceptable } \\
\text { value }\end{array}$ & $\begin{array}{l}\text { An extensive study on renewable } \\
\text { energy sources and climate } \\
\text { change mitigation using various } \\
\text { literature studies. }\end{array}$ & $\begin{array}{l}\text { Harmonization } \\
\text { Method }\end{array}$ \\
\hline $\begin{array}{l}\text { Viebahn et al. } \\
(2011)\end{array}$ & 33.4 & Spain and Algeria & $\begin{array}{l}\text { 50MW CSP parabolic trough } \\
\text { which uses thermal oil as the } \\
\text { HTF and molten salt for the } \\
\text { storage system }\end{array}$ & $\begin{array}{l}\text { Studies the potential role of solar } \\
\text { CSP in Africa and Europe, by } \\
\text { modeling case A in Spain and } \\
\text { case B in Algeria with solar } \\
\text { irradiation between 2000 for case } \\
\text { A and for case B 2500kWh/m }\end{array}$ & $\begin{array}{l}\text { Life cycle } \\
\text { assessment }\end{array}$ \\
\hline Current Study & 32.2 & South Africa & $\begin{array}{l}\text { 100 MW CSP parabolic } \\
\text { trough and two tank molten } \\
\text { salt storage using thermal oil } \\
\text { as the HTF }\end{array}$ & $\begin{array}{l}\text { An LCA study to quantify the } \\
\text { external costs associated with } \\
\text { the life cycle of the plant with } \\
\text { solar irradiation of 2900kWh/m² }\end{array}$ & $\begin{array}{l}\text { Life cycle } \\
\text { assessment }\end{array}$ \\
\hline
\end{tabular}




\subsection{Externality studies in South Africa}

Externality cost analysis research has gained prominence in South Africa, in order to understand the unaccounted costs of electricity generation. Various studies were conducted for the generation phase of coal fired power plant to determine the external cost associated with producing electricity using coal. In 2003 a study on electricity and externalities was performed by Spalding-Fecher and Matibe (2003), to broaden the knowledge presented in a previous research done by Van Horen (Van Horen, 1996a, Van Horen, 1996b) on externality analysis of electric power generation in South Africa (Spalding-Fecher and Matibe, 2003). This research evaluated the external costs involved in the production of electricity. The environmental impacts were quantified and evaluated by using the damage cost approach. The research found that "the central estimates of external costs were $40 \%$ and $20 \%$ of industrial and residential tariffs respectively". These results were inclusive of both negative and positive externalities. The authors made recommendations on future research studies to expand on the externality research and include more energy sources e.g. gas fired, nuclear and renewable.

Thopil and Pouris (2010) explored the trends of externality research in power generation for South Africa along international lines. The effects of harmful pollutants $\left(\mathrm{SO}_{2}, \mathrm{NO}_{x}\right.$, Particulates and $\mathrm{CO}_{2}$ eq) emitted during electricity production were evaluated in a more recent study (Thopil and Pouris, 2015). These harmful pollutants are associated with risks that cause human respiratory issues or are harmful to the environment. The study found that the central estimates of external costs were approximately $70 \%$ of 2008 electricity prices. The author shared that there is a need to diversify the energy sector and allow clean sources an equal opportunity to compete in the market. The quantification of external costs were accounted using the ExternE methodology. ExternE methodology follows the life cycle model and was developed in Europe as part of the ExternE projects, where the process of cost evaluation is called Impact-Pathway-Approach (Bickel and Friedrich, 2005).

In the South African studies the impact pathway method was used and this method is another form of LCA. Table 2 provides an overview of the main externality studies conducted in South Africa with costs adjusted for inflation (6\% assumed average inflation for the 2017 calculation). The cost adjustments enable a better understanding for studies performed over different time periods.

Table 2: Summary of externality studies in South Africa

\begin{tabular}{|l|l|l|}
\hline Authors & $\begin{array}{l}\text { Externality costs } \\
\text { (ZA c/kWh) }\end{array}$ & $\begin{array}{l}\text { Externality costs (ZA } \\
\text { c/kWh) 2017 }\end{array}$ \\
\hline (Van Horen, 1996a) & $2.23-12.45(1994)^{\star}$ & $8.5-47.55$ \\
\hline (Thopil and Pouris, 2015) & $5.79-35.19(2008)^{\star}$ & $9.8-59.5$ \\
\hline (Spalding-Fecher and Matibe, 2003) & $1.40-9.30(1999)^{\star}$ & $4.0-26.5$ \\
\hline
\end{tabular}

*Base year for which externality costs have been calculated

\section{Methodology}

Figure 2 shows the system boundary of the analysed solar CSP plant which take into account the various phases of the CSP plant life cycle. The study adopted the lifecycle assessment as defined by the ISO (2006) standards. LCA is a preferred model to perform environmental impact assessment for different energy systems both renewable (Klein and Rubin, 2013) and non-renewable (Bickel and Friedrich, 2005). The life cycle boundary aided the study in determining the entire life cycle of the solar plant, where the boundary consisted of the following phases: 
- Manufacturing phase includes the extraction and production of the solar CSP plant components. The Solar CSP plant comprises of three key systems solar field (collector field) (SF), heat transfer system (HTF), the thermal storage system (TES), and the power plant (PP) with the steam turbine and the generator (Viebahn et al., 2008).

- Construction phase refers to the activities related to the construction of the manufactured plant components together with the transportation from production to the construction of the solar CSP plant components.

- Operation and Maintenance phase includes the electricity consumption from the regional grid to the power auxiliary loads.

- Dismantling phase- The dismantling phase refers to the energy required to dismantle the power plant.

- Disposal Phase-The disposal phase refers to the waste management of the solar CSP plant

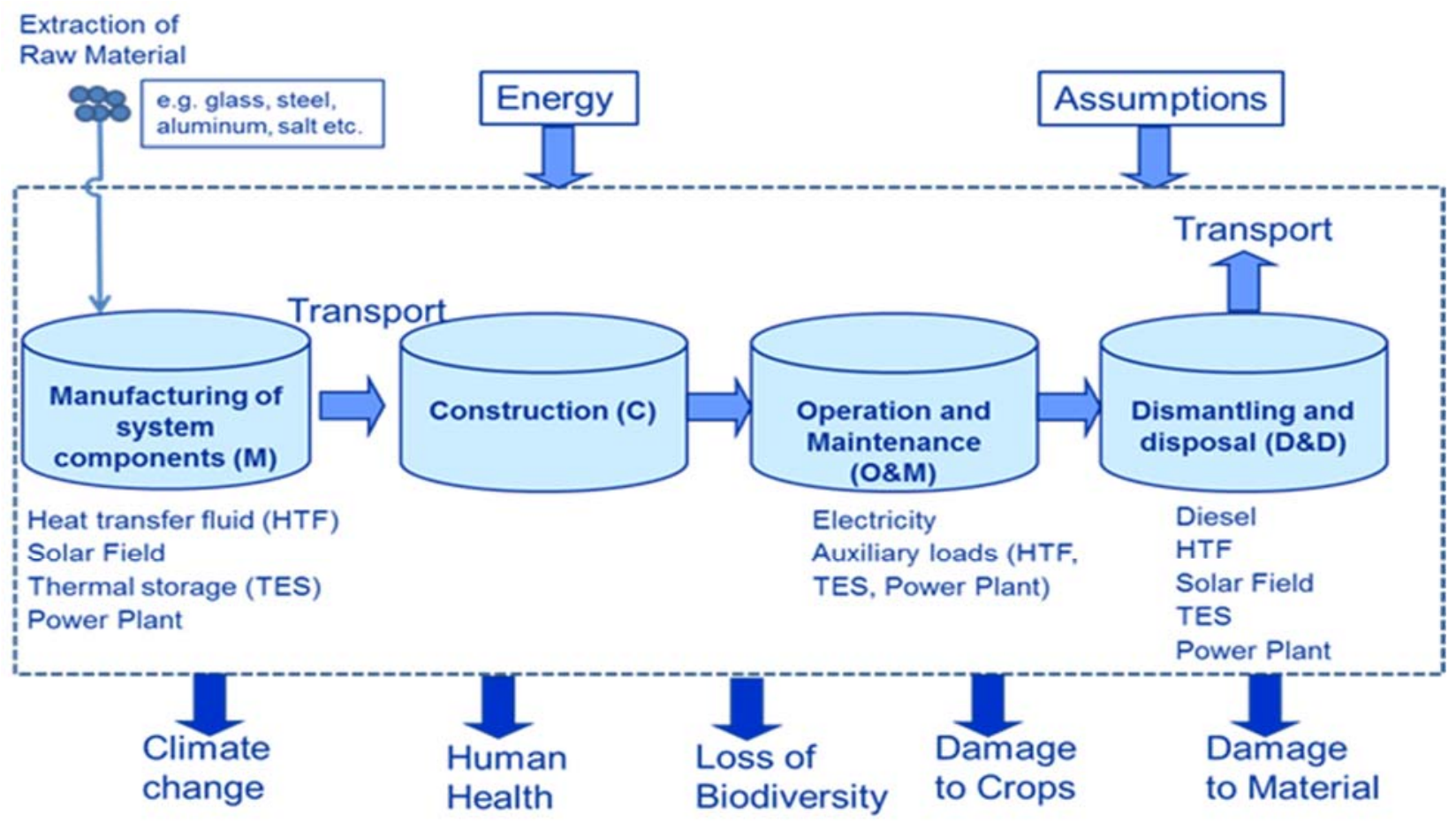

Figure 2: Environmental Lifecycle phases the CSP power plant Adapted from Klein and Rubin (2013)

The LCA approach is divided into two portions; the process portion and the monetary evaluation portion. The framework was therefore adapted to calculate the impacts as well as the damage cost and this is illustrated in Figure 3. 


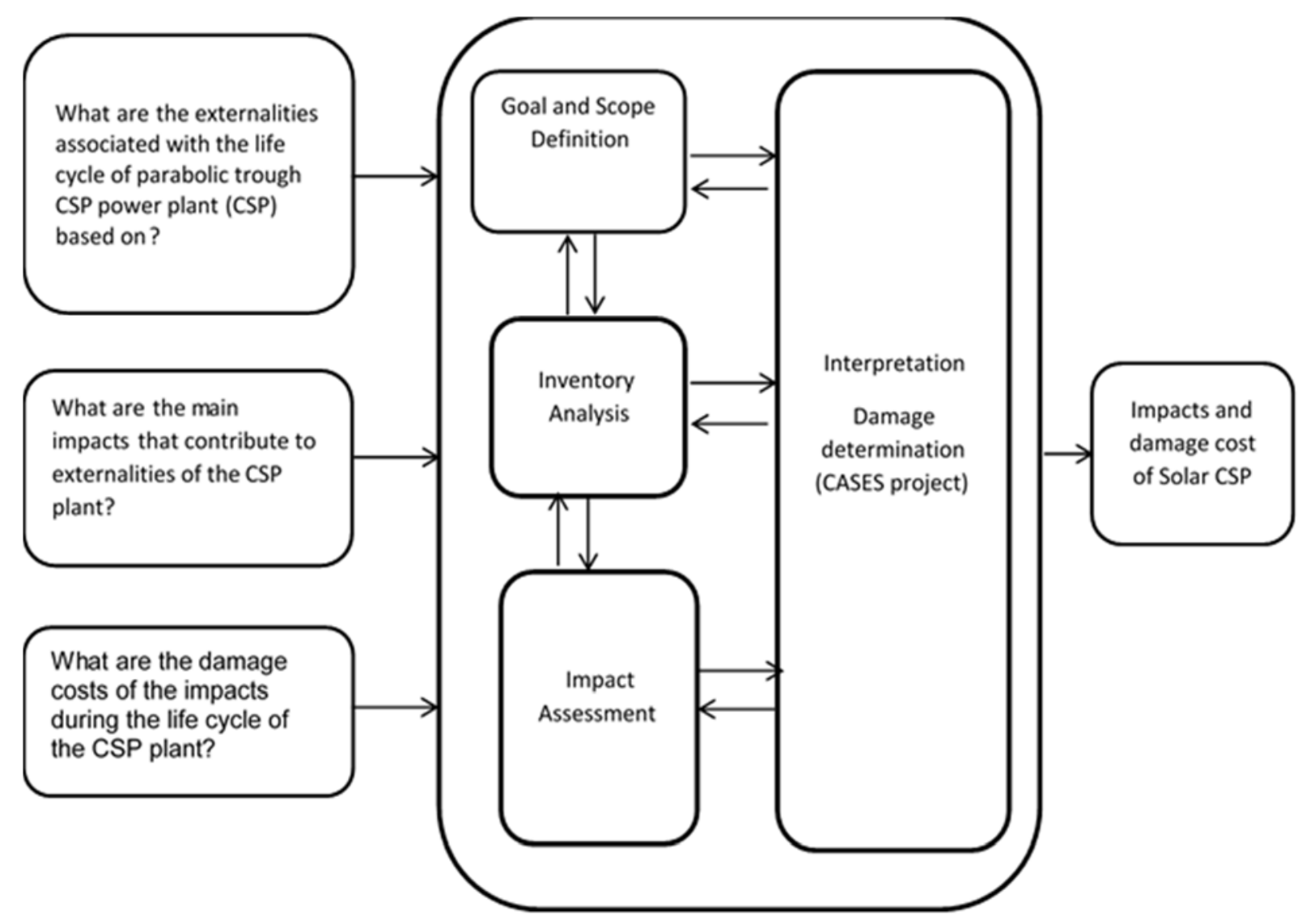

Figure 3: Methodological framework adapted from ISO (2006)

\subsection{Study Assumptions}

A range of assumptions were used while implementing processes using the LCA tool for each life cycle phase. Since inventory data was not available for the KaXu One power plant, the study relied on the inventory data from Burkhardt III et al. (2011). Burkhardt III et al. (2011) performed a similar study with the aim of determining the life cycle impact of a Solar CSP with a focus on parabolic trough and the impacts of key design alternatives. The assumptions used in this study for each phase of the life cycle are described in Table 3.

Table 3. Description of each phase within the LCA

\begin{tabular}{|l|l|}
\hline Phase & Assumptions \\
\hline Manufacturing & $\begin{array}{l}\text { This process phase involves the production of the different component } \\
\text { data calculated using Equations 1,2 and } 3 \text { to determine the mass of the } \\
\text { inventory component for the manufacturing phase of the solar CSP. The } \\
\text { motors, pumps, heaters and turbines do not form part of the system } \\
\text { components in Appendix A (table A.2). These non-system components } \\
\text { are considered to go through an extreme manufacturing process where } \\
\text { the impacts cannot be simply calculated by the manufacturer (Burkhardt III } \\
\text { et al., 2011). Therefore the economic input-output life cycle assessment } \\
\text { (EIO-LCA) method was used to model life cycle impacts of these } \\
\text { components. The ElO-LCA estimates the impacts associated with various } \\
\text { economical active materials. The emissions are then calculated using the } \\
\text { LCA tool where each major system is modelled as a separate plan and in } \\
\text { each plan the component material is used to represent the processes and } \\
\text { flows required to manufacture each system. The emissions in each plan } \\
\text { were then calculated and noted. }\end{array}$ \\
\hline
\end{tabular}




\begin{tabular}{|c|c|}
\hline Construction & $\begin{array}{l}\text { This phase considers the transportation of the major components which } \\
\text { include HTF, solar glass, steam cycle and solar salt which are not } \\
\text { produced locally but sourced in different countries around the world. The } \\
\text { embodied mass of the material was estimated using equations } 1,2 \text { and } 3 \\
\text { to calculate the mass from the reference plant in (Pihl et al., 2012). Lastly } \\
\text { this phase also included the diesel burned during the construction where } \\
\text { the diesel burned during construction is proportional to the land area of the } \\
\text { CSP plant (Viebahn et al., 2008). The LCA model included different plans for } \\
\text { the major systems of the solar CSP and in each plan the transport } \\
\text { together with the estimated distances was modelled in each plan, the } \\
\text { diesel burned in machines to manufacture the different systems was also } \\
\text { modelled with reference to the different land requirements of each solar } \\
\text { CSP system. }\end{array}$ \\
\hline $\begin{array}{l}\text { Operation and } \\
\text { Maintenance }\end{array}$ & $\begin{array}{l}\text { This phase considered the electricity consumed by the plant at night when } \\
\text { there is no direct sunlight. (Burkhardt III et al., 2011) was used as a } \\
\text { reference plant. Given the fact that the CSP plant in the Burkhardt III et al. } \\
\text { (2011) study has a 3\% difference in capacity compared to the KaXu Solar } \\
\text { one solar plant, a } 3 \% \text { difference was assumed to calculate the energy } \\
\text { consumed by the plant. The LCA model included the HTF night time } \\
\text { circulation, the power block dependent loads and the salt pump where the } \\
\text { percentage of consumption was calculated from (Burkhardt III et al., 2011) }\end{array}$ \\
\hline Dismantling & $\begin{array}{l}\text { Using a similar assumption as in the construction phase, where the diesel } \\
\text { burned during the dismantling phase was assumed to be proportional to } \\
\text { the land area of the CSP plant like in the Andasol } 1 \text { (Viebahn et al., 2008) } \\
\text { CSP plant, the assumption was also made in the Burkhardt III et al. (2011) } \\
\text { and (Corona et al., 2016) for a similar study The LCA model for this phase } \\
\text { was made up of one plan with the process and flows of the diesel burned } \\
\text { during dismantling for the total land area occupied by the CSP plant. }\end{array}$ \\
\hline Disposal & $\begin{array}{l}\text { The disposal phase assumed that the material is landfilled and disposed } \\
\text { as part of municipal waste (Crawford, 2009), mainly because South Africa } \\
\text { disposes off almost all of its refuse in landfill sites (Eyetwa Moses Maleka } \\
\text { et al., 2010). However the salt and HTF were considered hazardous and } \\
\text { therefore returned to the manufacture ,which was a similar analogy made } \\
\text { in (Burkhardt III et al., 2011). The concrete, glass and cement were } \\
\text { modelled as inert waste and the rest of the material was modelled as } \\
\text { municipal solid waste landfill and lastly the transport element during } \\
\text { disposal for the HTF was also modelled. }\end{array}$ \\
\hline
\end{tabular}

This study adapted inventory data from Burkhardt III et al. (2011) and the mass inputs were calculated using scaling factors equations 1,2 and 3. A similar method of data sourcing was adopted by Corona et al. (2016), Klein and Rubin (2013) and Wolfram et al. (2016) in their study which makes it an acceptable method of inventory data collection.

Table A.1 (within the Appendix) shows a list of the component data for each of the power plant systems. The embodied mass of the material was calculated using the equations from the Pihl et al. (2010) and Pihl et al. (2012) research study; where Equation 1 shows a linear relationship between the mass of the solar field components and the plant capacity. The capacity of the solar plant determines the number of trough mirrors to be installed in the solar field. Hence the HTF will follow suit since it runs in each of the troughs. 


$$
\mathrm{m}_{\text {study(solar field or HTF) }}=\mathrm{m}_{\text {ref (solar field or HTF) }}\left(\frac{C_{\text {study }}}{C_{\text {ref }}}\right)
$$

$C_{\text {study }}$ and $\mathrm{m}_{\text {study(solar field or HTF) }}$ is the thermal capacity and the mass of the solar field or HTF components of power plant of interest respectively; $C_{\text {ref }}$ and $\mathrm{m}_{\text {ref(solar field or HTF) }}$ represent the

thermal capacity and mass of the solar field or HTF components of the reference plant, respectively from Burkhardt III et al. (2011)

Equation 2 shows the investment cost equation which is assumed to give the relationship between the component mass of the thermal cycle (power plant) and the plant capacity since they do not have a linear relationship with the output. This equation was determined through communication with a steam turbine manufacture in the Pihl et al. (2010) study.

$$
\mathrm{m}_{\text {study(Power Plant) }}=\mathrm{m}_{\text {ref(Power Plant) }}\left(\frac{C_{\text {study }}}{C_{\text {ref }}}\right)^{0.89}
$$

$\mathrm{m}_{\text {study(Power Plant) }}$ is the mass of the power plant components power plant of interest; $\mathrm{m}$ ref(Power Plant) represents the mass of the power plant components of the reference plant, from Burkhardt III et al. (2011)

Equation 3 shows an area to volume scale which is an assumed relationship between the mass of the storage tank components and the plant capacity Pihl et al. (2010), (Pihl et al., 2012).

$$
\mathrm{m}_{\text {study (TES) }}=\mathrm{m}_{\text {ref(TES) }}\left(\frac{C_{\text {study }}}{C_{r e f}}\right)^{\frac{2}{3}}
$$

$\mathrm{m}_{\text {study(TES) }}$ is the mass of the thermal storage components of power plant of interest; $\mathrm{m}_{\text {ref(TES) }}$ represents the mass of the thermal storage components of the reference plant from Burkhardt III et al. (2011)

The motors, pumps, heaters and turbines do not form part of the system components since they go through an extreme manufacturing process where the impacts cannot be simply calculated by the manufacturer (Burkhardt III et al., 2011). The economic input-output life cycle assessment (EIO-LCA) method was used to model life cycle impacts of these components and the dataset details for these components are given in Table A.2.

\subsection{LCA evaluation tool to determine the impacts}

The educational licence version of GaBi LCA evaluation software (Thinkstep GaBi) and Ecoinvent databases (Weidema et al., 2013) were used for the study analysis. Ecoinvent was specifically used in cases where GaBi did not have the specified process to provide the emissions. Ecoinvent is a life cycle inventory $(\mathrm{LCl})$ database that consists of data for all economic activities and is accessible worldwide. It provides reliable background data to form part of the life cycle assessment studies (Weidema et al., 2013). It has also been widely used in various LCA literature studies for a range of renewable energy across the world such as, in Australia (Wolfram et al. (2016)), in the USA (Klein and Rubin (2013)), in Spain (Corona et al. (2016)) and Arvizu et al. (2011). 


\subsection{Damage (externality) cost Calculation}

The damage cost of each subcategory was then calculated using equation 4 where the damage is the product of the impact and the unit cost relative to the externality (Thopil, 2013).

$$
\text { Damage } \quad=\text { Impact } \times \text { Cost }
$$

Where, $\quad$ Damage = the total monetary cost

$$
\begin{array}{ll}
\text { Impact } & =\text { the total number of cases per externality } \\
\text { Cost } & =\text { monetary value per case of externality }
\end{array}
$$

Table 4 shows the subcategories and descriptions of each emission evaluated in the

\begin{tabular}{|c|c|}
\hline External costs subcategories & Description \\
\hline Climate change & $\begin{array}{l}\text { Marginal Damage Costs for Greenhouse Gases } \\
\text { according to IPCC } 2013 \text { (Stocker, 2014) }\end{array}$ \\
\hline Human health & $\begin{array}{l}\text { Damage costs derived from human mortality and } \\
\text { morbidity due to air emissions of } \mathrm{NH}_{3} \text {, Non- } \\
\text { Methane Volatile Organic Compounds (NMVOC), } \\
\mathrm{NO}_{x} \text {, Primary Particulate Matter "coarse" with an } \\
\text { aerodynamic diameter smaller than } 10 \mu \mathrm{m} \text { but } \\
\text { larger than } 2.5 \mu \mathrm{m}\left(\mathrm{PM} \mathrm{M}_{\mathrm{co}}\right) \text {, Primary Particulate } \\
\text { Matter with an aerodynamic diameter smaller } \\
\text { than } 2.5 \mu \mathrm{m}\left(\mathrm{PM}_{2.5}\right) \text { and } \mathrm{SO}_{2} \text {, }\end{array}$ \\
\hline Loss of biodiversity & $\begin{array}{l}\text { Damage costs from impacts on fauna and flora } \\
\text { due to acidification and eutrophication (caused } \\
\text { by air emissions of } \mathrm{NH}_{3}, \mathrm{NMVOC}, \mathrm{NO} \mathrm{O}_{x}, \mathrm{PPM} \text {, } \\
\mathrm{SO}_{2} \text { ) }\end{array}$ \\
\hline $\begin{array}{l}\text { Local effects on crops: } \\
\text { Regional } \mathrm{N} \text { and } \mathrm{O}_{3}\end{array}$ & $\begin{array}{l}\text { Damage cost from crop losses due to } \mathrm{O}_{3} \text { and } \\
\text { expected benefit from nitrogen deposition in soil } \\
\text { (avoidance of fertilizers) }\end{array}$ \\
\hline Damage to materials: $\mathrm{SO}_{2}$ and $\mathrm{NO}_{2}$ & $\begin{array}{l}\text { Damage costs of air pollution affecting building } \\
\text { materials (corrosion and soiling) }\end{array}$ \\
\hline
\end{tabular}
analysis.

Table 4: External costs sub-categories for the LCC assessment

Source: (Corona et al., 2016)

The marginal damage cost in Table 5 from CASES (2008) was used to calculate the damage cost for the climate change emissions. The CASES dataset for emissions from an unknown height was applied since the height of emissions was not known and is shown in Table 6. The currency conversion between EU and South Africa was calculated using the exchange rate from OECD Stat (2017).

Therefore a currency conversion rate of R15 for $1 €$ was used for the 2017 cost calculations. The rate was used to convert the marginal damage cost for GHG emissions in Table 5 and health related pollutants in Table 6, respectively to ZA (Rands). As indicated in Table 6, four separate impact categories were analysed, with multiple pollutants contributing within each category. These values were then used as cost inputs in equation 4. 
Table 5: Marginal costs for greenhouse gas emissions

\begin{tabular}{|l|l|l|l|}
\hline & Low estimate & Central Estimate & High Estimate \\
\hline$€ / \mathrm{t} \mathrm{CO} 2$ eq & 10 & 25 & 35 \\
\hline $\mathrm{ZA}$ (Rands)/t $\mathrm{CO}_{2}$ eq & 150 & 375 & 525 \\
\hline $\mathrm{ZA}$ (Rands)/kg CO $2 \mathrm{eq}$ & 0.15 & 0.375 & 0.525 \\
\hline
\end{tabular}

Euro values obtained from (CASES, 2008)

Table 6: Euro per kg unknown height for emissions year specified (2017)

\begin{tabular}{|c|c|c|}
\hline Country: & $\begin{array}{l}\text { EU27 } \\
\text { Euro/kg }\end{array}$ & $\begin{array}{l}\text { ZA (Rands)/ kg } \\
\text { (calculated) }\end{array}$ \\
\hline \multicolumn{3}{|c|}{ Human Health } \\
\hline $\mathrm{NH}_{3}$ & 4.70 & 70.5 \\
\hline NMVOC & 0.191 & 2.87 \\
\hline $\mathrm{NOx}$ & 5.334 & 80.01 \\
\hline PPMco & 1.112 & 16.69 \\
\hline PPM25 & 19.422 & 291.33 \\
\hline $\mathrm{SO}_{2}$ & 5.376 & 80.65 \\
\hline \multicolumn{3}{|c|}{ Loss of Biodiversity } \\
\hline $\mathrm{NH}_{3}$ & 2.771 & 41.57 \\
\hline $\mathrm{NOx}$ & 0.729 & 10.94 \\
\hline $\mathrm{SO}_{2}$ & 0.162 & 2.43 \\
\hline \multicolumn{3}{|c|}{ Local Effect on Crops: } \\
\hline NMVOC & 0.062 & 0.93 \\
\hline $\mathrm{NOx}$ & 0.263 & 3.95 \\
\hline \multicolumn{3}{|c|}{ Damage to Materials } \\
\hline $\mathrm{NOx}$ & 0.042 & 0.64 \\
\hline $\mathrm{SO}_{2}$ & 0.153 & 0.23 \\
\hline
\end{tabular}

Euro values in year 2000 terms obtained from (CASES, 2008)

\section{Results and Discussion}

The results show the analysis followed to estimate the external cost of the KaXu solar one CSP plant, which also includes the impacts calculated using the GaBi software based on the framework and methodology indicated in the previous sections.

The concept of functional unit as defined in the ISO (2006) standards, as a measured performance of a product system for use as a reference unit, is used to analyse and interpret the results (ISO, 2006). It provides a reference to normalise the data in order to compare the different systems being studied and it is represented as an impact per unit of delivered service. In the case, the results were normalised to a functional unit of $1 \mathrm{kWh}$. The KaXu Solar One plant has a capacity of 100MW (and a capacity factor of 36.5\%) which implies and annual output of $320000 \mathrm{MWh}$ of electricity as per the specification characteristics in section 3. Over a 20 year life cycle this would translate to a total output of $6400 \mathrm{GWh}$ of electricity generated by the power plant. The total damages GHG and non GHG damages in monetary value are then divided by $6400 \mathrm{GWh}$ to arrive at damage costs per kWh. This process aids comparisons between different technologies over a life cycle period.

Table 7: Impacts over the life cycle of the CSP plant

\begin{tabular}{|c|c|c|}
\hline $\begin{array}{c}\text { Externality sub- } \\
\text { categories }\end{array}$ & $\begin{array}{c}\text { Impact } \\
\text { g/kWh }\end{array}$ & $\begin{array}{c}\text { Impact per Life cycle phase } \\
\text { (g/kWh) }\end{array}$ \\
\hline
\end{tabular}




\begin{tabular}{|c|c|l|l|l|l|}
\hline & & M & C & O\&M & D\&D \\
\hline $\begin{array}{c}\text { Climate Change (GHG } \\
\text { eq) }\end{array}$ & $32.2^{1}$ & 14.1 & 3.1 & 7.3 & 7.7 \\
\hline \multicolumn{5}{|l|}{} \\
\hline Human health & 0.214 & 0.093 & 0.046 & 0.021 & 0.054 \\
\hline Loss of biodiversity & 0.149 & 0.061 & 0.038 & 0.011 & 0.039 \\
\hline Local effects on crops & 0.130 & 0.032 & 0.041 & 0.013 & 0.045 \\
\hline Damage to materials & 0.122 & 0.039 & 0.037 & 0.011 & 0.034 \\
\hline Total non GHG & 0.615 & 0.224 & 0.162 & 0.056 & 0.172 \\
\hline
\end{tabular}

Table 7 illustrates the impacts associated with each sub category in relation to each life cycle phase. It is evident from the table that that climate change emissions are higher than the other emissions. In the climate change sub category the highest contribution $\left(14.1 \mathrm{gCO}_{2^{-}}\right.$ $\mathrm{eq} / \mathrm{kWh}$ ) to the total impact was from the manufacturing phase as shown in Figure 4 . This was due to the intensive production processes of different components material; the most evident in the analysis was the salt and solar glass manufacturing processes. The O\&M and D\&D phase emissions are high in the climate change subcategories because of the electricity consumption, diesel and transportation requirements.

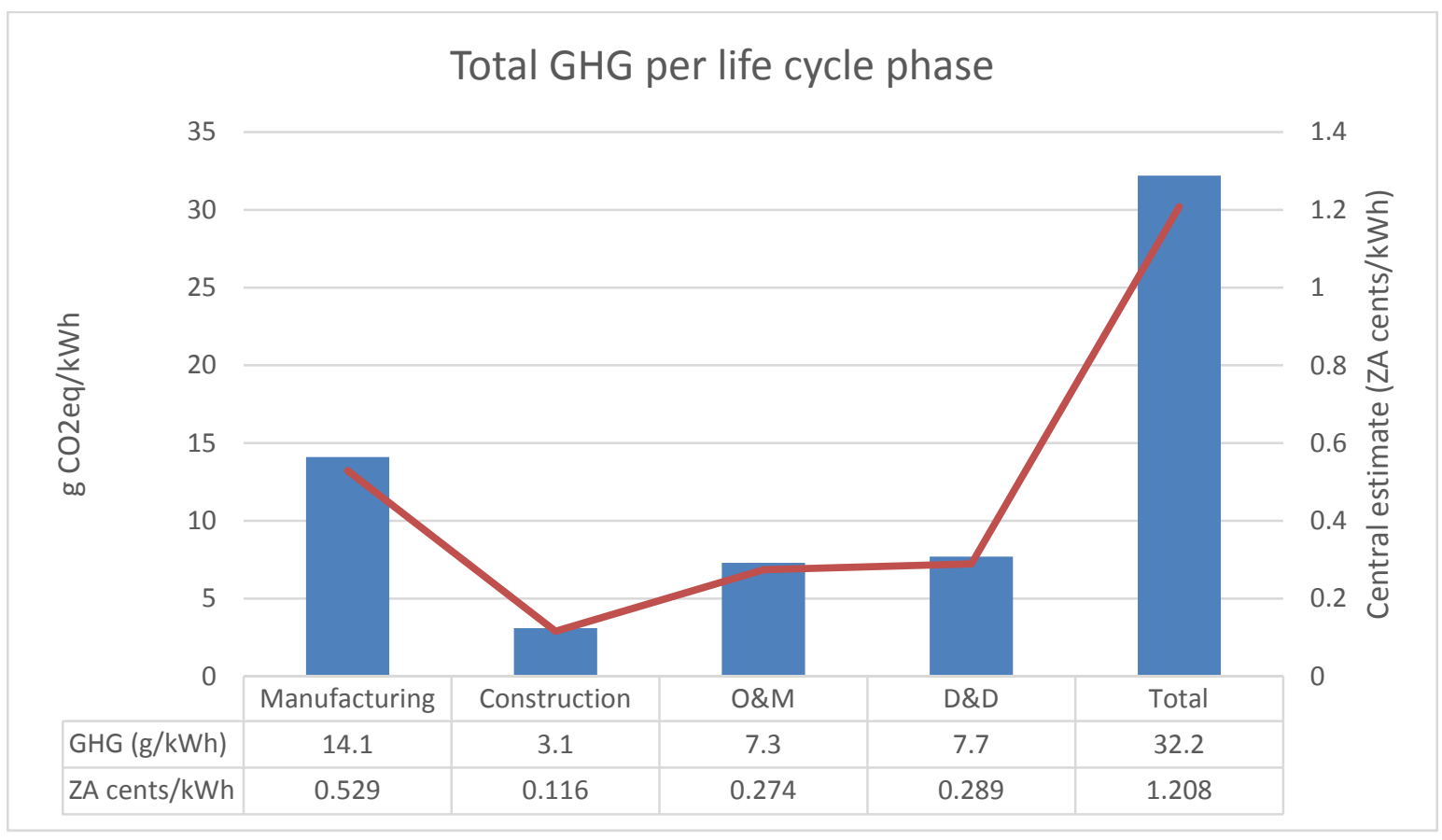

Figure 4. Total GHG damages vs impact over each life cycle phase

In the human health sub category; the highest contribution also was from the manufacturing phase due to high emissions of ammonia, sulphur dioxide and nitrogen oxides. This is also evident in Figure 5, where the manufacturing phase damage cost $(0.7 \mathrm{c} / \mathrm{kWh})$ is higher than the other phases. The manufacturing phase was also seen as the highest contributor to the emissions in the loss of biodiversity subcategory due to higher contribution of nitrogen oxides. This result was also similar for the damage to materials sub category, due to high emissions in sulphur dioxide.

\footnotetext{
${ }^{1} \mathrm{gCO}_{2}$ eq for climate change
} 


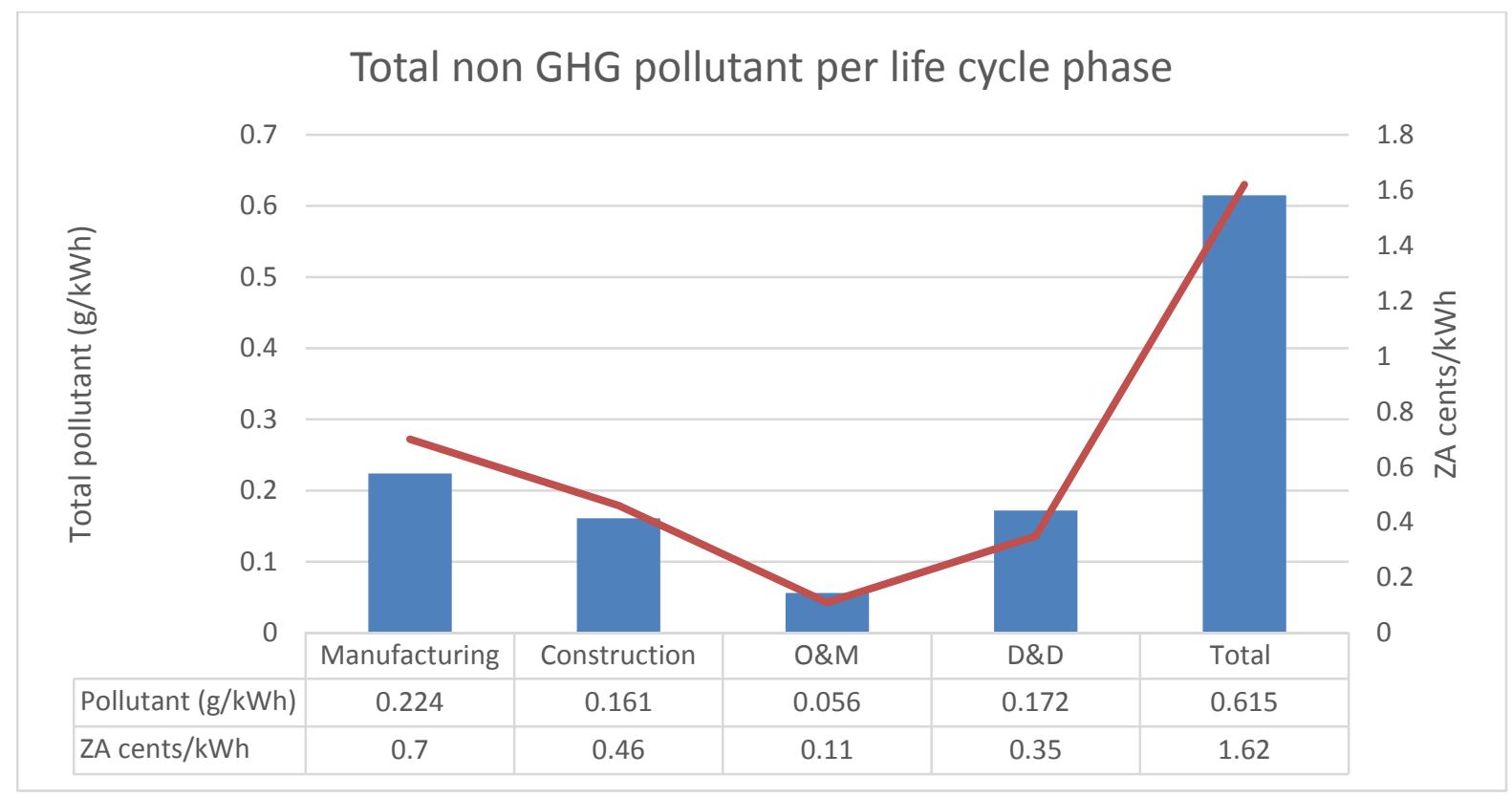

Figure 5. Total non GHG pollutant damages vs impact over each life cycle phase

As shown in figure 6 (and Table 7) the manufacturing phase contributes to $43.4 \%$ of the impact in the human health category, to $24.6 \%$ of the impacts attributed to damage to crops. The construction phase, contributes highly (31.5\%) to the damage to crops category. Pollutant emissions during the O\&M are comparatively low across all life cycle phases.

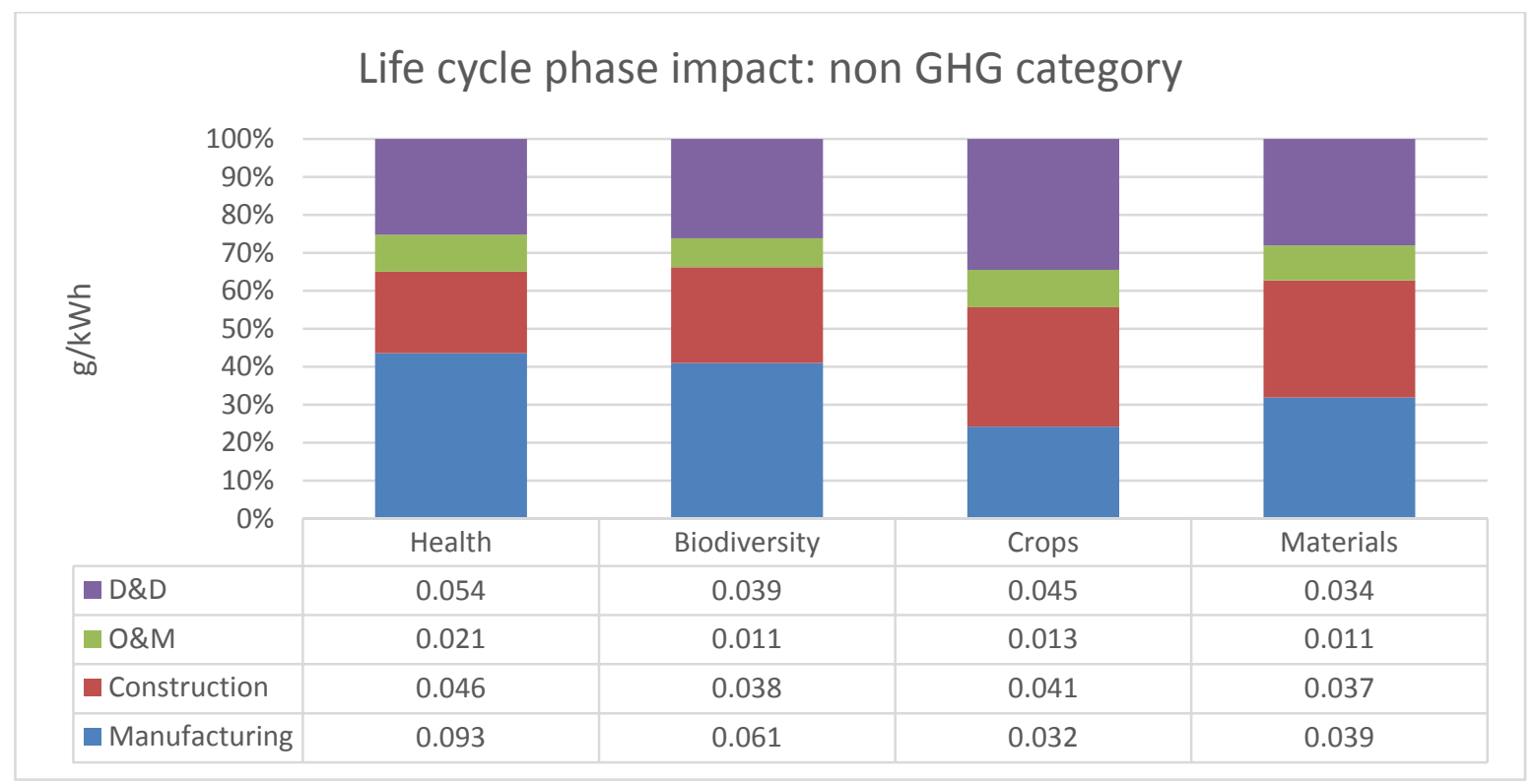

Figure 6. Breakdown of impacts per life cycle vs non GHG categories

Table 8 shows the overall results from the study including the external cost. It is interesting to note that though the impacts of the climate change category $\left(32 \mathrm{~g} \mathrm{CO}_{2} \mathrm{eq} / \mathrm{kWh}\right.$ ) are much greater than the impacts pollutants on human health $(0.214 \mathrm{~g} / \mathrm{kWh})$ the damages attributed to human health $(1.37 \mathrm{ZA} \mathrm{c} / \mathrm{kWh})$ are higher than the damage attributed to climate change (central estimate of $1.21 \mathrm{ZA} \mathrm{c} / \mathrm{kWh}$ ). This is due to the higher cost evaluation of pollutants that contribute to human health effects as compared to climate change (see Table 5 and 6). 
Table 8: External costs associated with the CSP plant

\begin{tabular}{|c|c|c|c|c|c|c|}
\hline \multirow[t]{2}{*}{$\begin{array}{l}\text { Externality sub- } \\
\text { categories }\end{array}$} & \multirow[t]{2}{*}{$\begin{array}{l}\text { Impact } \\
\text { g/kWh }\end{array}$} & $\begin{array}{c}\text { External Cost / sub } \\
\text { category }\end{array}$ & M & C & O\&M & D\&D \\
\hline & & \multicolumn{5}{|c|}{ ZA c/kWh } \\
\hline \multirow{3}{*}{$\begin{array}{c}\text { Climate Change } \\
\text { (GHG eq) }\end{array}$} & \multirow{3}{*}{32.2} & 0.48 (low) & 0.211 & 0.046 & 0.109 & 0.115 \\
\hline & & 1.21 (central) & 0.529 & 0.116 & 0.274 & 0.289 \\
\hline & & 1.69 (high) & 0.74 & 0.163 & 0.383 & 0.40 \\
\hline Human health & 0.214 & 1.37 & 0.568 & 0.404 & 0.096 & 0.301 \\
\hline Loss of biodiversity & 0.149 & 0.202 & 0.117 & 0.041 & 0.006 & 0.036 \\
\hline Local effects on crops & 0.130 & 0.039 & 0.008 & 0.014 & 0.002 & 0.014 \\
\hline Damage to materials & 0.122 & 0.013 & 0.006 & 0.0025 & 0.002 & 0.0026 \\
\hline Total non GHG & 0.615 & 1.624 & 0.7 & 0.461 & 0.106 & 0.353 \\
\hline \multirow{3}{*}{ Total External Cost } & \multirow{3}{*}{--- } & 2.10 (low) & 0.911 & 0.508 & 0.216 & 0.469 \\
\hline & & 2.83 (central) & 1.23 & 0.578 & 0.380 & 0.640 \\
\hline & & 3.31 (high) & 1.44 & 0.625 & 0.490 & 0.760 \\
\hline
\end{tabular}

The construction phase results are closely followed by the D\&D phase again due to the assumed transportation requirements for this study. In the D\&D phase, it was assumed that the material is landfilled and disposed as part of municipal waste (Crawford, 2009), mainly because South Africa disposes of, almost all of refuse in landfill sites (Eyetwa Moses Maleka et al., 2010). This excluded the salt and the HTF which is returned to the manufacture (Burkhardt III et al., 2011) because these are considered hazardous material.

The results indicate that the total damage cost range: $2.10 \mathrm{ZA} \mathrm{c} / \mathrm{kWh}(1.4 € / \mathrm{MWh}$, low estimate), $2.83 \mathrm{ZA} \mathrm{c/kWh}$ (1.9 €/MWh, central estimate), and $3.31 \mathrm{ZA} \mathrm{c/kWh} \mathrm{(2.2} \mathrm{€/MWh,}$ high estimate). It was also observed during the study that $\mathrm{NH}_{3}, \mathrm{SO}_{2}$ and $\mathrm{NO}$ x were the major emissions that repeated in all the categories. The local effects on crops and damage to material for the solar CSP plant may be classified as having low damage costs in comparison to the other sub-categories.

The results comparison in this section only compares the results for the climate change sub category since it was found to be the highest contributor to the environmental impact results. The numbers from Table 1 were compared with the results determined in this study and the comparison is illustrated in Figure 7.

In Figure 7 it is evident that the values reported in literature range from 14-33.4 $\mathrm{g} \mathrm{CO}_{2}$ $\mathrm{eq} / \mathrm{kWh}$, which equates to a damage cost range of 0.14-1.172 $€ / \mathrm{MWh}$. The values calculated in the analysed CSP results from this current study are in the range of $32.2 \mathrm{~g} \mathrm{CO}_{2} \mathrm{eq} / \mathrm{kWh}$, which equates to a damage cost range of $0.32-1.13^{3} € / \mathrm{MWh}$. it can also be observed from Figure 7 that there exist some slight variations between the results from this study and the literature. The highest variation being $18 \mathrm{~g} \mathrm{CO}_{2}$ eq/ $\mathrm{kWh}(56.3 \%$ lower than the analysed solar CSP plant) which was reported by Arvizu et al. (2011). This variation observed from Arvizu et al. (2011) results can be explained by the study having a rather wide range of references, hence the wide range in the environmental impact results. However the analysed CSP results from the current study are within the wide reported range.

\footnotetext{
${ }^{2}$ Calculated using low and high cost value in table 5 (14kg/MWh $\left.\times 0.01 € / \mathrm{kg} ; 33.4 \mathrm{~kg} / \mathrm{MWh} \times .35 € / \mathrm{kg}\right)$

${ }^{3}$ Similar logic to footnote 2
} 
The second highest variation of $6 \mathrm{~g} \mathrm{CO}_{2} \mathrm{eq} / \mathrm{kWh}$ (25\% lower than the analysed solar CSP plant) is between the analysis by Burkhardt et al. (2012) and the analysed solar CSP result in this study. Burkhardt et al. (2012) used the harmonization method to get an estimate of the GHGs for the solar CSP. The arguments from the article was that the article provided an approximation of the GHG emissions for a solar CSP plant and that the generic method of performing LCA is dependent on various factors; with that, they may reasonably differ from the results obtained by the harmonization method.

Due to the maturity of data internationally, the CSP studies incorporate real data from the actual CSP plant and hence this can also explain the variations observed in the current study and that presented in literature. Although there might exist small differences in the study model. The analysed solar CSP plant results are within the range presented in literature with very minimal variations, which implies that the results of the current study in the climate change category are in line with those reported in other studies.

The case study research design means that the study is performed on a unique case and the depending plant capacity, life cycle boundary authors assumptions the results may differ. Furthermore the slight variations in the results with the overall literature studies can also be attributed by the different transportation requirements; different analysis tools used which can significantly influence the overall impact.

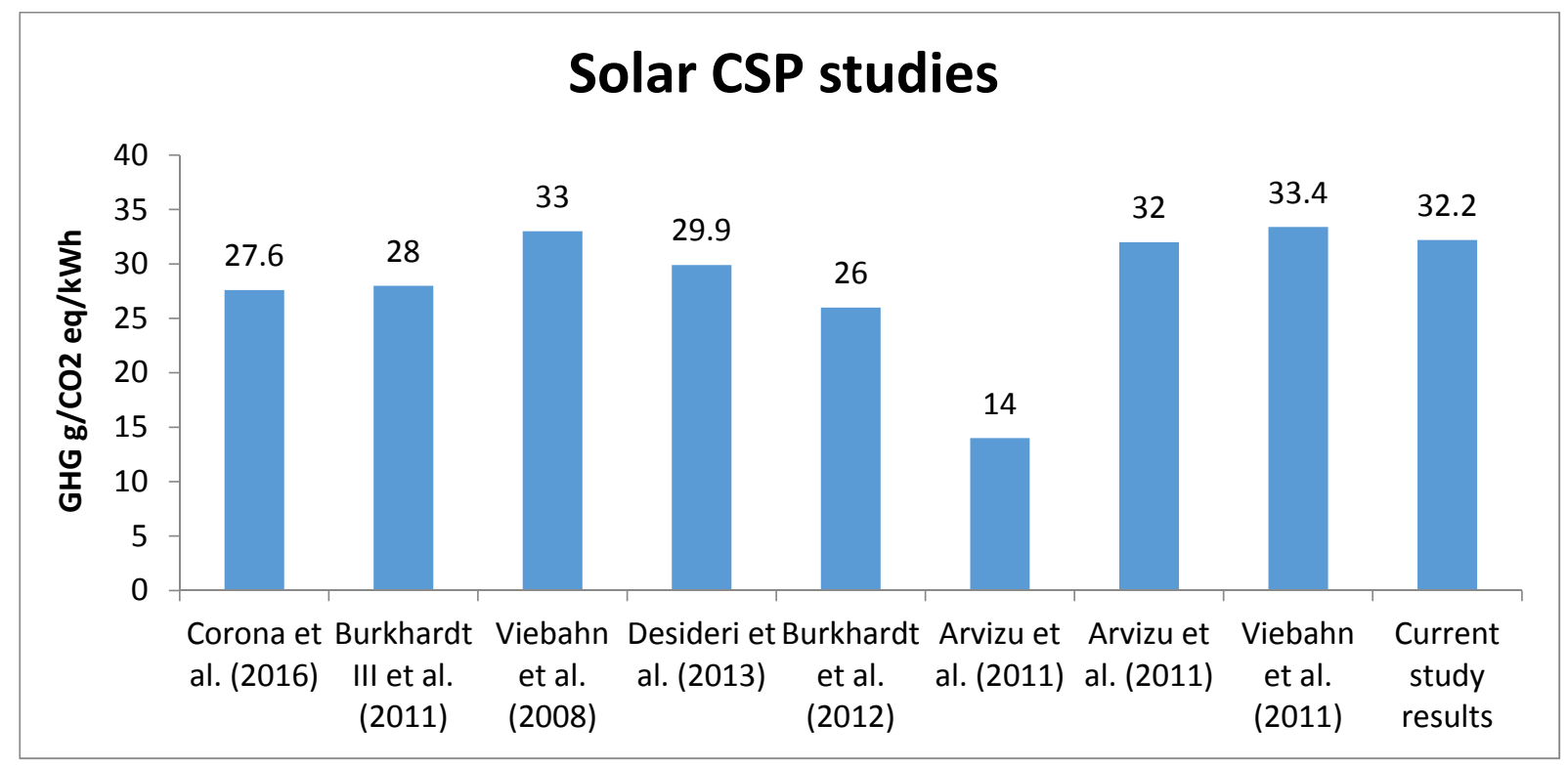

Figure 7: Comparison of climate change impacts of CSP technologies ${ }^{4}$

\section{Conclusions}

The LCA results from the study in Table 8 illustrated that the damage cost for the solar CSP was $2.10 \mathrm{ZA} \mathrm{c/kWh}$ (1.4 €/MWh, low estimate), $2.83 \mathrm{ZA} \mathrm{c} / \mathrm{kWh}$ (1.9 €/MWh, central estimate), and $3.31 \mathrm{ZA} \mathrm{c/kWh}(2.2 € / \mathrm{MWh}$, high estimate). The results also showed that the climate change results attributed to $43 \%$ of the total cost when considering the central estimate. The second highest emissions were from the human health subcategory which attributed to $48 \%$ of the central estimate. These two categories combined contributed to roughly $91 \%$ of the total central estimate external cost.

\footnotetext{
${ }^{4}$ Arvizu et al (2011) provides a range of $14-32 \mathrm{~g} \mathrm{CO}_{2} \mathrm{eq} / \mathrm{kWh}$
} 
The manufacturing phase was found to be a major contributor for almost all of the subcategories, which is due to the energy required to manufacture the system components of the solar CSP. The second highest contributor to the climate change subcategory is the dismantling and disposal phase due to the transportation requirements of the solar salt and the HTF since these are very hazardous components and existing studies suggested returning the components to the manufacturer, which prompted the assumption that these components be returned to the manufacturer and leading to transportation overseas. The O\&M phase had a minimal contribution to the total impact since the amount of energy required for the operation of the plant is very low. The construction phase was the second highest contributor to the external cost for most of the other subcategories which was due to the effect of nitrogen oxides, ammonia and sulphur dioxide emitted during transportation of the major components from overseas. The loss of biodiversity subcategory was discussed in the investigation by Vezmar et al. (2014) as a disadvantage for the solar CSP plant. However in the South African context this effect is minimal on flora and fauna together with wildlife, since most of the CSP plants are located in the desert areas in the Northern Cape. Hence the benefits of locating the CSP plants in the desert were also suggested in Turney and Fthenakis (2011).

The manufacturing phase contributes to $43.5 \%$ of the total results for the central estimate. This is then followed by the D\&D phase which attributes to $22.6 \%$ primarily because of the transportation of hazardous material back to the manufacturer. The construction phase contributes significantly to the other externalities outside the climate change category and this is again is due to the transport factor emissions with overall contribution being $20.4 \%$ to the total damage cost. The O\&M phase which requires low operating energy therefore has the lowest damage cost contribution of $13.4 \%$ towards to total central estimate damage cost.

The comparison analysis between the GHG emissions produced during the LCA of the analysed CSP (KaXu Solar One) plant shows that the results are in line with those reported in other literature studies which range between 14 to $33.4 \mathrm{~g} \mathrm{CO}_{2} \mathrm{eq} / \mathrm{kWh}$ (leading to a damage cost of $0.14-1.17 € / \mathrm{MWh}$ ), with slight variations which can probably explained by the difference in transportation requirements. The South African CSP manufacturing sector is dependent on the import of major CSP components from developed countries such as USA, Germany and Spain which manufacture the elements within the country thereby reducing the impacts caused by the transport activities. The study also hopes to create debate within private industry to provide data, thereby enabling to verify the analysis by incorporating primary data.

Another major contribution of the study is that the external cost calculation can be compared to the internal costs of CSP in South Africa. The internal cost of CSP (at which independent power producers sell to the utility) for the 1st bid window in the REIPPPP - of which the CSP plant was part of - was R2.7/kWh (PPIAF, 2014). The central external cost of 2.83c/kWh (as shown in Table 8), is therefore roughly $1 \%$ of the internal cost, with the low and high external costs being, $0.08 \%$ and $1.2 \%$ respectively. However CSP external cost are low compared to conventional external cost central estimates of $13 \mathrm{c} / \mathrm{kWh}$ (Thopil \& Pouris, 2015). It is important to note that the estimation of conventional external costs were limited to the generation phase and not the full life cycle.

Over the past decade average South African electricity prices have increased at a rate much higher than inflation (PPIAF, 2014). However average utility electricity prices of $0.83 R / \mathrm{kWh}$ (Eskom, 2017) are still lower than most recent CSP internal cost of 1.64R/kWh (PPIAF, 2014), with differences being expected to narrow as utility price increases and renewable costs decrease. Therefore the component of external costs relating to the internal costs are bound to be vary because of the dynamic nature of electricity prices. 


\section{Recommendations}

The world today is on a drive to reduce greenhouse gases. Renewable energy based electricity generation has enabled reduction of greenhouse gases to a large extent. However even renewable based electricity technologies tend to have unaccounted impacts and damages. Externality studies provide a real picture of the real cost of producing electricity and the emissions produced during the production of electricity for various technologies. This research study and other research studies found that the solar CSP plant can produce electricity with less greenhouse gases compared to those emitted by fossil fuels. Furthermore the function of the thermal storage system of a solar CSP plant is to store energy to be used at a later stage, which gives solar CSP plants an advantage against the other renewable technologies. This feature mitigates the intermittency associated with renewables to a certain extent.

From the results and discussion section, it can be concluded that the location of these plants should be carefully considered to reduce the effect on human health, impact on crops and loss of biodiversity. This study also found that the transport requirements for the main components of the solar CSP plant attribute to high emissions. Hence the local community, environment and economy can benefit if manufacturing of the main components are localised, thereby reducing the emissions caused by the transport activities. While expanding local manufacturing activities can be challenging due to open markets and decreasing costs of solar CSP components, mechanisms can be put in place to identify higher quality production which is incentivised by national policy. Emphasis on manufacturing improved quality of components can lead to innovation and R\&D within the national sphere.

The results of this study applied engineering life cycle analysis. However there remains a level of uncertainty, which may have led to an over or under estimation of the results. The solar CSP plants in South Africa are still fairly new; which used assumptions (particularly on plant material inventory) based on similar studies conducted internationally. Hence the results of the study can be verified and improved by obtaining inventory data from an operational CSP plant in South Africa. Therefore future research can augment the current work by using primary inventory data from the actual CSP plant, and from the international suppliers in order to get the exact quantity embodied by each material, enabling an accurate inventory analysis of the system. Future research can also look at the LCA for solar tower operated CSP plants as well as other renewable technologies in South Africa thus enabling comparisons of environmental impacts and costs.

\section{References}

ARVIZU, D., BALAYA, P., CABEZA, L., HOLLANDS, T., JÄGER-WALDAU, A., KONDO, M., KONSEIBO, C., MELESHKO, V., STEIN, W. \& TAMAURA, Y. 2011. Direct solar energy. IPCC Special Report on Renewable Energy Sources and Climate Change Mitigation. Cambridge, United Kingdom and New york,USA: Cambridge University Press.

BICKEL, P. \& FRIEDRICH, R. 2005. ExternE: Externalities of Energy Methodology 2005 Update [Online]. Europe: European Communities. Available: https://ec.europa.eu/research/energy/pdf/kina_en.pdf [Accessed 31 March 2016 2016].

BURKHARDT III, J. J., HEATH, G. A. \& TURCHI, C. S. 2011. Life cycle assessment of a parabolic trough concentrating solar power plant and the impacts of key design alternatives. Environmental science \& technology, 45, 2457-2464.

BURKHARDT, J. J., HEATH, G. \& COHEN, E. 2012. Life cycle greenhouse gas emissions of trough and tower concentrating solar power electricity generation. Journal of Industrial Ecology, 16, S93-S109.

CARNEGIE MELLON UNIVERSITY GREEN DESIGN INSTITUTE. 2017. Economic Input-Output Life Cycle Assessment (EIO-LCA) US 2002 (428 sectors) Producer model [Online]. Available: http://www.eiolca.net [Accessed 26 July 2017].

CASES. 2008. Cost Assessment of Sustainable Energy Systems [Online]. Available: http://www.feemproject.net/cases/ [Accessed 08 September 2016]. 
CHEN, Z.-M., LIU, Y., QIN, P., ZHANG, B., LESTERD, L., CHEN, G., GUO, Y. \& ZHENG, X. 2015. Environmental externality of coal use in China: Welfare effect and tax regulation. Applied energy, 156, 16-31.

CHIANG, Y. H., LI, J., ZHOU, L., WONG, F. K. W. \& T.I. LAM, P. 2015. The nexus among employment opportunities, life-cycle costs, and carbon emissions: a case study of sustainable building maintenance in Hong Kong. Journal of Cleaner Production, 109, 326-335.

CORONA, B., CERRAJERO, E., LÓPEZ, D. \& SAN MIGUEL, G. 2016. Full environmental life cycle cost analysis of concentrating solar power technology: Contribution of externalities to overall energy costs. Solar Energy, 135, 758-768.

CRAWFORD, R. 2009. Life cycle energy and greenhouse emissions analysis of wind turbines and the effect of size on energy yield. Renewable and Sustainable Energy Reviews, 13, 2653-2660.

DESAI, N. B. \& BANDYOPADHYAY, S. 2015. Optimization of concentrating solar thermal power plant based on parabolic trough collector. Journal of Cleaner Production, 89, 262-271.

DESIDERI, U., ZEPPARELLI, F., MORETTINI, V. \& GARRONI, E. 2013. Comparative analysis of concentrating solar power and photovoltaic technologies: Technical and environmental evaluations. Applied energy, 102, 765-784.

DOE 2013. Integrated Resource Plan For Electricity (IRP). In: ENERGY, D. O. (ed.). Pretoria.

ESKOM 2017. Integrated Annual Report. Sandon, South Africa.

EYETWA MOSES MALEKA, LINDIWE MASHIMBYE \& PHILIP GOYNS 2010. South African Energy Synopsis 2010. In: ENERGY, D. O. (ed.). Pretoria: Department of Energy.

FIELDSTONE AFRICA. 2017. Fieldstone Africa Renewable index [Online]. Available: http://www.fieldstoneafrica.com/fieldstoneafrica/FARI [Accessed 25 May 2017].

GEORGAKELLOS, D. 2012. Climate change external cost appraisal of electricity generation systems from a life cycle perspective: the case of Greece. Journal of Cleaner Production, 32, 124-140.

HUENTELER, J., NIEBUHR, C. \& S.SCHMIDT, T. 2016. The effect of local and global learning on the cost of renewable energy in developing countries. Journal of Cleaner Production, 128, 6-21.

IEA. 2017. South Africa: Electricity and Heat for 2015 [Online]. [Accessed 01/01/2018 2018].

ISO, E. 2006. 14040: 2006. Environmental management-Life cycle assessment-Principles and framework.

KAXU SOLAR ONE (PTY) LTD. 2012. NERSA KaXu Solar One license application - public hearing [Online]. Available:

https://www.google.co.za/url?sa=t\&rct=j\&q=\&esrc=s\&source=web\&cd=1\&cad=rja\&uact=8\&ved=0a hUKEwjT_paZgYXRAhWIJMAKHQ4tA8QQFggZMAA\&url=http\%3A\%2F\%2Fwww.nersa.org.za\%2FAdmi n\%2FDocument\%2FEditor\%2Ffile\%2FConsultations\%2FElectricity\%2FPresentations\%2FKa\%2520Xu\% 2520Solar\%25200ne\%2520(Pty)\%2520Limited.pdf\&usg=AFQjCNG4d3dv8feN44I7HiKI61Rt17auXA\&b vm=bv.142059868,d.d2s [Accessed 20 August 2016].

KHAN, J. \& ARSALAN, M. H. 2016. Solar power technologies for sustainable electricity generation-A review. Renewable and Sustainable Energy Reviews, 55, 414-425.

KLEIN, S. J. \& RUBIN, E. S. 2013. Life cycle assessment of greenhouse gas emissions, water and land use for concentrated solar power plants with different energy backup systems. Energy Policy, 63, 935-950.

KURAVI, S., TRAHAN, J., GOSWAMI, D. Y., RAHMAN, M. M. \& STEFANAKOS, E. K. 2013. Thermal energy storage technologies and systems for concentrating solar power plants. Progress in Energy and Combustion Science 39, 285-319.

LECHON, Y., DE LA RÚA, C. \& ROSA, S. 2008. Life cycle environmental impacts of electricity production by solarthermal power plants in Spain. Journal of Solar Energy Engineering, 130, 021012.

MEYERHOFF, J., OHL, C. \& HARTJE, V. 2010. Landscape externalities from onshore wind power. Energy Policy, 38, 82-92.

NATIONAL RENEWABLE ENERGY LABORATORY. 2016. Concentrating Solar Power Projects [Online]. Available: http://www.nrel.gov/csp/solarpaces/index.cfm [Accessed 13 August 2016].

OECD STAT. 2017. Organisation For Economic Co-Operation And Development [Online]. Available: https://stats.oecd.org/Index.aspx?DataSetCode=SNA TABLE4 [Accessed 22 May 2017].

PETERSEIM, J. H., WHITE, S., TADROS, A. \& HELLWIG, U. 2014. Concentrating solar power hybrid plantsenabling cost effective synergies. Renewable energy, 67, 178-185. 
PIHL, E., HEYNE, S., THUNMAN, H. \& JOHNSSON, F. 2010. Highly efficient electricity generation from biomass by integration and hybridization with combined cycle gas turbine (CCGT) plants for natural gas. Energy, 35, 4042-4052.

PIHL, E., KUSHNIR, D., SANDÉN, B. \& JOHNSSON, F. 2012. Material constraints for concentrating solar thermal power. Energy, 44, 944-954.

PPIAF, 2014. South Africa's Renewable Energy IPP Procurement Program: Success factors and Lessons. PPIAF, Washington DC.

RENTIZELAS, A. \& GEORGAKELLOS, D. 2014. Incorporating life cycle external cost in optimization of the electricity generation mix. Energy Policy, 65, 134-149.

RUDMAN, J., GAUCHÉ, P. \& ESLER, K. J. Initial review and analysis of the direct environmental impacts of CSP in the northern Cape, South Africa. AIP Conference Proceedings, 2016.

SAN MIGUEL, G. \& CORONA, B. 2014. Hybridizing concentrated solar power (CSP) with biogas and biomethane as an alternative to natural gas: Analysis of environmental performance using LCA. Renewable energy, 66, 580-587.

SEN, B., ERCAN, T. \& TATARI, O. 2017. Does a battery-electric truck make a difference? - Life cycle emissions, costs, and externality analysis of alternative fuel-powered Class 8 heavy-duty trucks in the United States. Journal of Cleaner Production, 141, 110-121.

SPALDING-FECHER, R. \& MATIBE, D. K. 2003. Electricity and externalities in South Africa. Energy policy, 31, 721-734.

STOCKER, T. 2014. Climate change 2013: the physical science basis: Working Group I contribution to the Fifth assessment report of the Intergovernmental Panel on Climate Change, Cambridge University Press.

THEREGOWDA, R., VIDIC, R., LANDIS, A., DZOMBAK, D. \& MATTHEWS, H. S. 2016. Integrating external costs with life cycle costs of emissions from tertiary treatment of municipal wastewater for reuse in cooling systems. Journal of Cleaner Production, 112, 4733-4740.

THINKSTEP GABI. What is GaBi Software [Online]. Available: http://www.gabi-software.com/southafrica/overview/what-is-gabi-software/ [Accessed 30 March 2017].

THOPIL, G. A. 2013. Externality valuation of non-renewable electricity generation in South Africa-an ExternE approach. University of Pretoria.

THOPIL, G. A. \& POURIS, A. 2010. An overview of the electricity externality analysis in South Africa within the international context. South African Journal of Science, 106, 1-6.

THOPIL, G. A. \& POURIS, A. Externality valuation in South Africa's coal based electricity generation sector. Technology Management in the Energy Smart World (PICMET), 2011 Proceedings of PICMET'11:, 2011. IEEE, 1-6.

THOPIL, G. A. \& POURIS, A. 2015. Aggregation and internalisation of electricity externalities in South Africa. Energy, 82, 501-511.

TSOUTSOS, T., FRANTZESKAKI, N. \& GEKAS, V. 2005. Environmental impacts from the solar energy technologies. Energy Policy, 33, 289-296.

TURNEY, D. \& FTHENAKIS, V. 2011. Environmental impacts from the installation and operation of large-scale solar power plants. Renewable and Sustainable Energy Reviews, 15, 3261-3270.

VAN HOREN, C. 1996a. Counting the social costs: Electricity and externalities in South Africa, University of Cape Town Press.

VAN HOREN, C. R. 1996b. The cost of power: externalities in South Africa's energy sector, publisher not identified.

VEZMAR, S., SPAJIĆ, A., TOPIĆ, D., ŠLIVAC, D. \& JOZSA, L. 2014. Positive and Negative Impacts of Renewable Energy Sources. International Journal of Electrical and Computer Engineering Systems, 5, 47-55.

VIEBAHN, P., KRONSHAGE, S. \& LECHON, Y. 2008. Deliverable n 12.2-RS la" Final report on technical data, costs, and life cycle inventories of solar thermal power plants. New Energy Externalities Developments for Sustainability (NEEDS) Integrated Project, EU 6th Framework Programme, Brussels.

VIEBAHN, P., LECHON, Y. \& TRIEB, F. 2011. The potential role of concentrated solar power (CSP) in Africa and Europe-A dynamic assessment of technology development, cost development and life cycle inventories until 2050. Energy Policy, 39, 4420-4430. 
WEIDEMA, B. P., BAUER, C., HISCHIER, R., MUTEL, C., NEMECEK, T., REINHARD, J., VADENBO, C. O. \& WERNET, G. 2013. Overview and Methodology.Data quality guideline for the ecoinvent database version 3. Ecoinvent Report 1(v3). St. Gallen:The Ecoinvent Centre

WOLFRAM, P., WIEDMANN, T. \& DIESENDORF, M. 2016. Carbon footprint scenarios for renewable electricity in Australia. Journal of Cleaner Production, 124, 236-245.

ZVINGILAITE, E. 2011. Human health-related externalities in energy system modelling the case of the Danish heat and power sector. Applied energy, 88, 535-544.

\section{Appendix}

The inventory data from Burkhardt III et al. (2011) was used in conjunction with equations 1 , 2 and 3 to calculate the mass inventory of the CSP plant under consideration and the results are represented in Table A.1

Table A.1: Main LCI Data (components) for KaXu Solar one for the manufacturing phase

\begin{tabular}{|c|c|c|c|}
\hline HTF System & $1.45 \mathrm{E}+04$ & $\begin{array}{l}\text { Power Plant } \\
\text { Systems }\end{array}$ & 7.71E+04 \\
\hline Material & Mass $\left[\times 10^{3} \mathrm{~kg}\right]$ & Material & Mass $\left[\times 10^{3} \mathrm{~kg}\right]$ \\
\hline Aluminum & $5.11 E+01$ & Aluminum & $1.84 \mathrm{E}+01$ \\
\hline Calcium Silicate & $6.37 E+01$ & Asphalt & $7.45 E+03$ \\
\hline Carbon Steel & $3.32 E+03$ & Brick & $2.44 \mathrm{E}+02$ \\
\hline Concrete & $5.71 E+03$ & Bronze & $6.95 \mathrm{E}-01$ \\
\hline Copper & $6.22 \mathrm{E}+00$ & Calcium Silicate & $3.02 \mathrm{E}+01$ \\
\hline Foam Glass & $2.35 \mathrm{E}+01$ & Carbon Steel & $2.21 \mathrm{E}+03$ \\
\hline Gravel & $7.58 \mathrm{E}+02$ & Cement & $4.80 E+01$ \\
\hline HTF & $4.15 E+03$ & Ceramic Tiles & $1.10 \mathrm{E}+01$ \\
\hline Iron & $3.80 E+00$ & Concrete & $1.88 \mathrm{E}+04$ \\
\hline Mineral Wool & $4.29 E+02$ & Copper & $6.61 E+01$ \\
\hline Nitrogen & $1.76 \mathrm{E}+01$ & Fiber Cement & $7.54 \mathrm{E}+01$ \\
\hline Stainless Steel & $2.17 \mathrm{E}+01$ & Fiber Glass & $4.45 \mathrm{E}-02$ \\
\hline Solar Field & $5.62 \mathrm{E}+04$ & Flat Glass & $1.03 E+01$ \\
\hline Material & Mass $\left[\times 10^{3} \mathrm{~kg}\right]$ & Foam Slab & $1.24 \mathrm{E}+01$ \\
\hline Aluminum & $1.62 E+01$ & Gravel & $4.71 E+04$ \\
\hline Carbon Steel & $1.67 \mathrm{E}+04$ & Iron & $3.55 E+01$ \\
\hline Ceramic Tiles & $1.57 \mathrm{E}+02$ & $\begin{array}{l}\text { Mineral Wool } \\
\text { Polyamide Thin }\end{array}$ & $3.07 E+01$ \\
\hline Concrete & $2.72 E+04$ & Film & $3.88 \mathrm{E}-01$ \\
\hline Copper & $5.57 \mathrm{E}+01$ & Polyethylene & $8.81 E+02$ \\
\hline Ferronickel & $1.02 E+01$ & PVC & $9.19 E+00$ \\
\hline Glue & $1.11 \mathrm{E}+01$ & Rubber & $2.73 E+00$ \\
\hline Iron & $4.69 \mathrm{E}+01$ & $\begin{array}{l}\text { Stainless Steel } \\
\text { Glass Fiber }\end{array}$ & $3.78 \mathrm{E}+01$ \\
\hline Low-Iron Glass & $1.10 \mathrm{E}+04$ & Reinforced plastic & $1.91 \mathrm{E}+01$ \\
\hline Nickel & $1.02 \mathrm{E}+00$ & TES & 7.65E+04 \\
\hline Paint & $2.11 E+02$ & Material & Mass $\left[\times 10^{3} \mathrm{~kg}\right]$ \\
\hline Polyethylene & 4.79E+00 & Aluminum & 5.10E-01 \\
\hline
\end{tabular}




\begin{tabular}{|c|c|c|c|}
\hline Polypropylene & $1.20 \mathrm{E}+00$ & Calcium Silicate & $1.38 \mathrm{E}+03$ \\
\hline PVC & $1.48 \mathrm{E}+01$ & Carbon Steel & $3.06 E+03$ \\
\hline Silver & $1.05 \mathrm{E}+00$ & Concrete & $9.90 E+03$ \\
\hline Stainless Steel & $8.11 E+02$ & Copper & $2.32 E+00$ \\
\hline \multirow{8}{*}{$\begin{array}{l}\text { Total Embodied Mass: } \\
2.24 \mathrm{E}+08 \quad \mathrm{~kg}\end{array}$} & & Fire Bricks & $2.57 E+02$ \\
\hline & & Foam Glass & $1.74 \mathrm{E}+02$ \\
\hline & & Iron & 8.21E-01 \\
\hline & & Polyethylene & $8.11 E+00$ \\
\hline & & Polypropylene & $7.79 E+01$ \\
\hline & & Potassium Nitrate & $2.43 E+04$ \\
\hline & & Sodium Nitrate & $3.65 E+04$ \\
\hline & & Stainless Steel & $8.15 E+02$ \\
\hline
\end{tabular}

Table A.2: EIO LCA data

\begin{tabular}{|c|c|}
\hline System components & Dataset name \\
\hline $\begin{array}{l}\text { HTF System } \\
\text { Heaters and heat exchangers } \\
\text { Pumping equipment }\end{array}$ & $\begin{array}{l}\text { \#332410: Power boiler and heat exchanger manufacturing } \\
\text { \#333911: Pump and pumping equipment manufacturing }\end{array}$ \\
\hline $\begin{array}{l}\text { Power Plant Systems } \\
\text { Steam cycle }\end{array}$ & $\begin{array}{l}\text { \#332410: Power boiler and heat exchanger manufacturing } \\
\text { \#332420: Metal tank, heavy gauge, manufacturing } \\
\text { \#333611: Turbine and turbine generator set units manufacturing } \\
\text { \#333911: Pump and pumping equipment manufacturing } \\
\text { \#334513: Industrial process variable instruments } \\
\text { \#335999: Miscellaneous electrical equipment manufacturing }\end{array}$ \\
\hline $\begin{array}{l}\text { Solar Field } \\
\text { Semiconductor } \\
\text { Instrumentation \& Control } \\
\text { System }\end{array}$ & $\begin{array}{l}\text { \#334413: Semiconductor and related device manufacturing } \\
\text { \#334513: Industrial process variable instruments } \\
\# 335314 \text { : Relay and industrial control manufacturing }\end{array}$ \\
\hline $\begin{array}{l}\text { TES } \\
\text { Pumping equipment }\end{array}$ & \#333911: Pump and pumping equipment manufacturing \\
\hline
\end{tabular}

Source: (Carnegie Mellon University Green Design Institute, 2017),(Burkhardt III et al., 2011) 